DOI: 10.32844/2222-5374-2020-104-2.21

УДК: 349.2

Коренькова В. С.,

здобувач Науково-дослідного інституту публічного права

\title{
ДОСВІД КРАЇН БАЛТІЇ У СФЕРІ ЄВРОПЕЙСЬКОЇ ТА ЄВРОАТЛАНТИЧНОЇ ІНТЕГРАЦЇ̈
}

Актуальність статті полягає в тому, що прагнучи забезпечити ефективну державну політику щодо реалізації національного курсу на європейську та євроатлантичну інтеграцію, дуже важливо звернути увагу на відповідний досвід зарубіжних країн, які вже здійснили дану інтеграцію іувійшли до ЄС та НАТО на правах повноправних членів. При цьому особливий інтерес для нас становить досвід країн, які набули членства у даних міжнародних об'єднаннях відносно недавно, а також на певному історичному етапі зазнали тиску з боку радянського режиму. Європейський Союз є унікальним явищем наддержавного демократичного утворення європейських країн. Високий рівень співпраці держав Європи в форматі ЄС приводить до того, що з кожним роком все більше і більше країн хочуть приєднатися до цієї організацї. Тому дослідження пройденого реформаційного шляху цих трьох держав має значний практичний інтерес для України. Першочергової уваги заслуговує досвід таких Балтійські країни як Естонія, Литва та Латвія. У статті, спираючись на аналіз наукових поглядів вчених, узагальнено досвід країн Балтії у сфері європейської та євроатлантичної інтеграції, на основі чого наголошено, що пережитки радянського минулого, на які часто посилаються українські політичні та державні діячі, обгрунтовуючи затягування і неефективність реформ, необхідних для повноцінної європейської та євроатлантичної інтеграції, не є настільки суттєвою перешкодою. Виокремлено найбільш позитивний досвід країн Балтії, який доцільно використати українському законодавцю. Зроблено висновок, що для якісної та дієвої реалізації Україною досліджуваного курсу необхідною є наявність узгодженої позиція політичних сил в країні з цього приводу, чого в нашій державі досягнути, поки що не вдалося. Звісно проголошення у Конституції України зазначеного курсу стало важливим кроком у цьому напрямку, однак на практиці у політичному житті країни й досі відбуваються запеклі дискусії з приводу необхідності та доцільності для України саме такого курсу. Небажання впливових політичних сил його визнавати значним чином гальмує прийняття та здійснення відповідних заходів у цьому напрямку. Зауважимо, що у зарубіжних країнах, зокрема у прибалтійських державах та Польщі, також відбувалися значна політична боротьба з питань інтеграції, однак, після офіційного визнання відповідного курсу, політичні дискусії та суперечки стосувалася питань доцільності чи недоцільності відповідних кроків і заходів щодо його реалізації, втім сам вибір не оспорювався та не піддавався критиці.

Ключові слова: зарубіжний досвід, європейська інтеграція, євроатлантична інтеграція, удосконалення, законодавство. 
Актуальність теми. Прагнучи забезпечити ефективну державну політику щодо реалізації національного курсу на європейську та євроатлантичну інтеграцію, дуже важливо звернути увагу на відповідний досвід зарубіжних країн, які вже здійснили дану інтеграцію і увійшли до ЄС та НАТО на правах повноправних членів. При цьому особливий інтерес для нас становить досвід країн, які набули членства у даних міжнародних об’єднаннях відносно недавно, а також на певному історичному етапі зазнали тиску з боку радянського режиму. Э. Ковтун у своїх наукових пошуках, присвячених проблематиці євроінтеграції України, зазначає, що Європейський Союз $€$ унікальним явищем наддержавного демократичного утворення європейських країн. Високий рівень співпраці держав Європи в форматі ЄС приводить до того, що з кожним роком все більше і більше країн хочуть приєднатися до цієї організації. Тому дослідження пройденого реформаційного шляху цих трьох держав має значний практичний інтерес для України [1]. Першочергової уваги заслуговує досвід таких Балтійські країни як Естонія, Литва та Латвія.

Стан дослідження. Окремі проблемні питання, пов'язані із європейською та євроатлантичною інтеграцією в Україні у своїх наукових працях розглядали: Є.І. Ковтун, С.О. Божко, С.А. Скриль, С.В. Ківалов, Л.І. Кормич, М.A. Польовий, О.А. Палій, О.В. Кокорєв та багато інших. Втім, незважаючи на чималу кількість наукових здобутків, в зазначеній сфері малодослідженим залишається ряд питань, зокрема пов'язаних із зарубіжним досвідом європейської та євроатлантичної інтеграції.

Саме тому метою статті є: узагальнити досвід країн Балтії у сфері європейської та євроатлантичної інтеграції та опрацювати можливості його використання в Україні

Виклад основного матеріалу. Після завершення міжблокового протистояння часів «холодної війни», зазначає С.О. Божко, Балтика зазнала значних геополітичних змін. Внаслідок дезінтеграційних процесів у Радянському Союзі кінця 1980-х - початку 1990-х років три прибалтійські країни - Литва, Латвія та Естонія - здобули свою незалежність. А вплив Росії в регіоні є значно меншим порівняно із роллю, яку відігравав СРСР [2]. Після здобуття незалежності ці три держави Балтії подібно до інших колишніх республік Радянського Союзу, що розпався, змушені були вирішувати комплекс складних економічних, політичних і соціальних питань та визначати стратегічні пріоритети у зовнішній політиці. Національна свідомість латишів, литовців та естонців сприйняла незалежність своїх держав як відтворення історичної справедливості, як акт повернення до західного світу, від якого вони були силоміць відторгнені радянською агресією. Відтак, держави Балтії відразу заявили про свою чітку прозахідну орієнтацію, а головною ціллю їх зовнішньої політики стала інтеграція до Європейського Союзу та НАТО [3].

Актуальність дослідження інтеграції саме балтійських держав до Європейського Союзу зумовлюється, справедливо відмічає М. Сидорук, рядом факторів. Цей процес мав низку особливостей, які тією чи іншою мірою знайомі і для України. Зокрема, ці держави мають з Росією спільні кордони; на їхніх територіях проживає значна кількість російськомовного населення; економіка країн Балтії була значною мірою зорієнтована на 
Росію, енергетична та сировинна залежність від РФ змушувала уряди цих держав шукати шляхи виходу з цієї ситуації тощо. Відтак, вивчення досвіду подолання цих проблем, як і загалом руху прибалтійських держав до об'єднаної Європи, є для України особливо важливим [3].

Включенню зазначених країн Балтії до складу ЄС передувало здійснення ними ряд реформ і перетворень на внутрішньодержавному рівні. 3окрема Є. Ковтун, аналізуючи умови інтеграції країн Балтії до ЄС, виокремив наступні кроки: створення умов для вільного пересування товарів. Мали бути скасовані митні платежі, кількісні обмеження та протекціоністські заходи. Технічні, гігієнічні та інші стандарти для товарів також підлягали гармонізації згідно з європейськими стандартами; забезпечення вільного пересування мешканців країн-членів у межах кордонів ЄС і збереження соціальних стандартів по всій території Європейського союзу; реформа сфери надання послуг. Згідно з європейським законодавством мали бути створені рівні можливості надання послуг як національними підприємствами, так і іноземними. Цілий комплекс законодавчих актів мав бути розроблений у банківській та телекомунікаційній сферах; гармонізація законодавства яке стосується підприємств різних форм власності. Стандартизація системи управління підприємствами, реформування механізмів захисту прав кредиторів та акціонерів; забезпечення вільної конкуренції в кожній країні. Створення дієвого антимонопольного законодавства; реформування законодавства, що стосується аграрного сектору. Особливо актуальним для країн Балтії було питання гармонізації законодавства у сфері риболовства, бо в цій галузі вони мають значний потенціал. Основна увага приділяється системі обмеження вилову риби, ліцензуванню, дослідницькій роботі зі збереження рибних ресурсів. Спеціальні документи регулюють об'єми експорту рибної продукції з цих країн; реформування транспортної сфери. Дотримання високих сервісних і екологічних стандартів було найважливішим фактором у даному процесі; стандартизація в галузі промисловості мала на меті: підвищити пристосування промисловості до структурних змін, в першу чергу це означає забезпечити її конкурентоспроможність в умовах єдиного ринку; впровадити єдині стандарти у виробництві; забезпечити належний рівень захисту навколишнього середовища [1]. Окремо слід відзначити те, що особливо важливими умовами швидкого реформування політичних систем у напрямку європейських стандартів виступили нормативні (конституційні, у першу чергу) та соціально-психологічні фактори, які мають певні історичні та культурні зв'язки з цінностями Західної цивілізації. С.А. Скриль вважає, що суттєвим $є$ те, що демократичні реформи у прибалтійських державах отримали масову соціально-психологічну підтримку різних верств населення. Таким чином у суспільстві сформувалась правосвідомість соціальної згоди, яка виступила «рушійною енергетикою» трансформаційних політичних процесів. За таких умов конституційні норми мають ознаки реальної, а не фіктивної (як, наприклад, в Україні та Російській Федерації) конституції. Автор зауважує, що вже на початку 90-х років минулого сторіччя у прибалтійських країнах сформувався полікратичний тип форми держави, головними ознаками якого є: «м'який» поділ державної влади (характерний для змішаних та парламентських республік), домінування інтересів середнього класу у розробці моделей політич- 
ної та економічної систем, багатопартійність, ефективні механізми захисту прав і свобод людини [4, с. 151].

3 викладеного видно, що для інтеграції в ЄС країнам Балтії довелося провести суттєві зміни у державній політиці, значна частина яких має на меті забезпечення соціально-економічних та фінансових аспектів суспільного життя. Звісно, реформи торкнулися й інших питань, зокрема таких як: свобода переміщення людини, правосуддя, протидія корупції, освіта, забезпечення безпеки довкілля тощо. Однак навіть ці реформи, у значній мірі, обумовлені потребами забезпечення ефективного та безперешкодного економічного та фінансового співробітництва країн, що, в цілому, відповідає меті створення Європейського союзу. Так, згідно Договору про Європейський Союз та Договору про функціонування Європейського Союзу з протоколами та деклараціями мета Союзу - підтримувати мир, свої цінності та добробут своїх народів. Союз надає своїм громадянам простір свободи, безпеки й правосуддя без внутрішніх кордонів, на якому забезпечено вільний рух осіб разом з належними заходами, пов'язаними із контролем на зовнішніх кордонах, притулком, імміграцією та попередженням і боротьбою зі злочинністю. Союз засновує внутрішній ринок. Союз функціонує заради сталого розвитку Європи, що грунтується на збалансованому економічному зростанні та ціновій стабільності, конкурентоспроможній соціальній ринковій економіці, спрямованій на цілковиту зайнятість та соціальний прогрес, та високому рівні захисту і дедалі кращому стані довкілля. Союз сприяє науково-технічному прогресові [5]. Слід відмітити, що за останні роки в нашій державі було зроблено ряд важливих кроків як у напрямку забезпечення політичних і громадських прав та свобод людини, і громадянина, так і щодо адаптації фінансово-економічної основи країни до вимог і стандартів $€ C$, втім без забезпечення високого рівня законності і дисципліни у поведінці учасників суспільних відносин (як приватних, так і публічних) зазначені соціально-економічні реформи не призведуть до бажаних наслідків в частині інтеграції до ЄС. Проблема, перш за все, полягає у дуже високому рівні корупції в країні. Так, згідно даних Transparency International, які щорічно публікують Індекс сприйняття корупції у 2019 році Україна погіршила свої позиції, втративши два бали. 30 балів зі 100 можливих - результат Індексу сприйняття корупції-2019 для України. Ми повернулися на рівень 2017 року і тепер посідаємо 126 місце зі 180 країн. Поруч з нами у рейтингу - Киргизстан, Азербайджан та Джибуті. Україна з-поміж сусідів випереджає Росію, яка зберегла свої позиції (28 балів, 137 місце). Очікувано серед сусідів лідирує Польща (58 балів, 41 місце) та Словаччина (50 балів, 59 місце). Білорусь додала один пункт і тепер має 45 балів та 66 місце. Також, цього року спостерігаємо зниження індексу у сусідів: Румунія - мінус 3 бали, Угорщина - на 2, Молдова на 1. Лідери СРI суттєво не змінилися. На першому місці - Нова Зеландія та Данія, які набрали по 87 балів. Примітно, що 8310 країн у першій десятці - представниці Західної та Північної Європи [6]. Проблеми із протидією корупції аж ніяк не сприяють прозорості фінансових потоків в країні, незалежності та неупередженості судових та державних контролюючих органів, розвитку добросовісної конкуренції та боротьбі з монополізмом в економіці. 
Що стосується інтеграції до НАТО, то тут, як слушно відмічає ряд дослідників, ключову роль при визначенні зовнішньополітичних пріоритетів країн Балтії відіграла «політична міфологія» - образ «давнього ворога Росії», яка проводить імперську політику щодо сусідніх менших народів та держав, та ідея «повернення до Європи» як відновлення історичної справедливості. Безальтернативна прозахідна орієнтація Латвії, Литви та Естонії дала їм підстави після набуття незалежності чітко і швидко визначитись у своїх головних стратегічних пріоритетах та векторах зовнішньої політики [7, с. 242]. Слід відзначити, що протягом другої половини 90-х років Латвія, Литва і Естонія декілька разів відкидали пропозиції Російської Федерації підписати Угоду з проблем безпеки у Балтійському регіоні і подали офіційні заяви на вступ до НАТО. 31994 р. ці країни стали членами Західноєвропейського Союзу, а з часу передачі функцій ЗЄС Європейському Союзу - членами програм ЄС. Усі країни Балтійського регіону є активними учасницями програми «Партнерство заради миру». Проте ні Латвії, ні Литві, ні Естонії не вдалось увійти до першої групи кандидатів для вступу в Альянс (1997-1999 рр.). Блокувала процес вступу Росія, яка виступала категорично проти включення до НАТО країн Балтійського регіону. У січні 1998 року між країнами Балтії - єдиними з пострадянських країн - і США як прибічником інтеграції цих держав у трансатлантичні структури було підписано Хартію про партнерство, у якій Вашингтон взяв на себе зобов'язання допомогти Латвії, Литві та Естонії підготуватись до вступу у Північно-Атлантичний Союз. Офіційні Вільнюс, Рига і Таллінн хоч і наголосили на тому, що розглядають підписання цього документа як додаткову можливість стати повноправними членами Альянсу, у той же час підкреслили, що Хартія не замінить їм членства у трансатлантичній структурі безпеки [8; 9]. Слід відзначити, що країни Балтії тривалий час виборювали своє право на одночасне входження до складу НАТО, однак суттєвою перепоною на цьому шляху були проблеми етнічного та громадянського характеру у Латвії та, у меншій мірі, Естонії, які вправно використовувала у своїх інтересах Російська Федерація. Однак, завдяки зусиллям політичних еліт Литви, Латвії та Естонії, які незважаючи на існуючі внутрішньодержавні політичні протистояння, зуміли консолідуватися самі та об'єднати абсолютну більшість свого населення у прагненні до євроатлантичної інтеграції, що посилило переконало НАТО у щирості намірів зазначених балтійських держав [9]. I вже у 2000-х роках, Альянс почав активно діяти на Балтійському напрямі. НАТО проводить заходи з приведення латвійських, литовських та естонських військ у відповідність зі стандартами Альянсу у сферах управління, розвідки, зв'язку та тилового забезпечення, фактично, країни Балтії вже отримали доступ до розвідувальної інформації НАТО, можливостей Альянсу щодо модернізації військової техніки та перекваліфікації особового складу. I нарешті 2004 році Литва, Латвія та Естонія були прийняті до Євроатлантичного Альянсу. Членство в НАТО, пише О.В. Кокорєв, було для країн Балтії одним з основних стратегічних завдань. 3 одного боку, воно задовольняло запити політичних еліт і створювало безпеку суспільству. 3 іншого боку, дозволило елітам позиціонувати свої країни як форпост проти Росії, прикордонну територію між Заходом і Сходом. Після вступу в Північноатлантичний блок перед країнами Балтії постала кілька склад- 
них завдань: підтримка (точніше, досягнення) рівня витрат на оборону в розмірі 2 \% ВВП; продовження реформування збройних сил і модернізація військової інфраструктури; участь у спільних військових операціях і навчаннях Альянсу; забезпечення патрулювання повітряного простору союзниками; підтримка політики «відкритих дверей» [10, с. 70].

Висновки. Отже, виходячи із вивчення досвіду зазначених країн, можемо з упевненістю стверджувати, що пережитки радянського минулого, на які часто посилаються українські політичні та державні діячі, обгрунтовуючи затягування і неефективність реформ, необхідних для повноцінної європейської та євроатлантичної інтеграції, не є настільки суттєвою перешкодою, за наявності наступних умов:

- по-перше, для якісної та дієвої реалізації Україною досліджуваного курсу необхідною $є$ наявність узгодженої позиція політичних сил в країні $з$ цього приводу, чого в нашій державі досягнути, поки що не вдалося. Звісно проголошення у Конституції України зазначеного курсу стало важливим кроком у цьому напрямку, однак на практиці у політичному житті країни й досі відбуваються запеклі дискусії з приводу необхідності та доцільності для України саме такого курсу. Небажання впливових політичних сил його визнавати значним чином гальмує прийняття та здійснення відповідних заходів у цьому напрямку. Зауважимо, що у зарубіжних країнах, зокрема у прибалтійських державах та Польщі, також відбувалися значна політична боротьба з питань інтеграції, однак, після офіційного визнання відповідного курсу, політичні дискусії та суперечки стосувалася питань доцільності чи недоцільності відповідних кроків і заходів щодо його реалізації, втім сам вибір не оспорювався та не піддавався критиці;

- по-друге, зміни мають не просто декларуватися, а бути забезпечені реальними діями, заходами та ресурсами;

- по-третє, спеціальний орган контролю за процесом інтеграції та координації діяльності органів виконавчої влади у цій сфері, має створюватися не урядом, а парламентом і бути підпорядкованим і підзвітним безпосередньо останньому. Такий підхід посилює участь парламенту у реалізації проголошеного європейського та євроатлантичного курсу.

- по-четверте, забезпечення ефективної протидії корупції. I держави Балтії, і Польща, на шляху інтеграції до ЄС та НАТО провели значну роботу у напрямку зміцнення законності та дисципліни в основних сферах суспільного життя, зокрема у галузі публічного управління, що є цілком зрозумілим. Адже за наявності високого рівня корупції, тіньової економіки, відсутності необхідно прозорості фінансових потоків не можливо забезпечити ані здорову конкуренцію, ані неупереджений та дієвий державний контроль, ані ефективний захист прав і законних інтересів учасників суспільних відносин.

\section{СПИСОК ВИКОРИСТАНИХ ДЖЕРЕЛ}

1. Ковтун Є. Досвід інтеграції Латвії, Литви та Естонії до Європейського союзу, як приклад для України. Емінак. 2008. № 1-4. С. 105-109.

2. Божко С. О. Геополітичне положення регіону Балтійського моря. Актуальні проблеми міжнародних відносин. 2014. Вип. 120(1). С. 127137. 
3. Сидорук М. Особливості інтеграції держав Балтії до ЄС. Наукові записки [Національного університету «Острозька академія»]. Сер. : Міжнародні відносини. 2010. Вип. 2. С. 97-104. URL: http://nbuv.gov.ua/UJRN/ Nznuoamv_2010_2_11

4. Скриль С. А. Трансформація політичних систем Латвї̈, Литви та Естонії в умовах інтеграції в європейське співтовариство. Актуальні проблеми політики: зб. наук. пр. / редкол.: С.В. Ківалов (голов. ред.), Л.І. Кормич (заст. голов. ред.), М.А. Польовий (відп. секр.) [та ін.]; НУ «ОЮА», Південноукр. центр гендер. проблем. Одеса : Фенікс, 2015. Вип. 54. С. 146-152.

5. Консолідовані версії Договору про Європейський Союз та Договору про функціонування Європейського Союзу з протоколами та деклараціями (Консолідовані версії станом на 30.03.2010) // [Електронний ресурс] Режим доступу: https://zakon.rada.gov.ua/laws/show/994_b06\#Text

6. Індекс сприйняття корупції-2019 / Transparency International Ukraine // URL: http://cpi.ti-ukraine.org/\#/

7. Інтеграційні виміри трансформації пострадянського простору: монографія / за редакцією кандидата історичних наук, доцента А.Г. Бульвінського; передмова доктора історичних наук, професора, член-кореспондента НАН України А.І. Кудряченка; ДУ «Інститут всесвітньої історії НАН України». К.: ДУ «Інститут всесвітньої історії НАН України», 2020.560 с.

8. Кононенко Н. Балабан Р. Україна Прибалтика: вектори співпраці. Людина і політика. 2000. № 4. С. 10-16.

9. Палій О. А. Специфіка та наслідки інтеграції країн Балтії до Євроатлантичних структур безпеки // Національний Наукові записки Національного університету «Києво-Могилянська Академія» / Національний, «Києво-Могилянська Академія» університет. Т. 20. Економічні науки.. Київ: КМ Академія, 2002, С. 55-60.

10. Кокорєв 0. В. Позитивні і негативні наслідки трансформації в країнах Балтії та вступу до ЄС. Вісник Донецького національного університету. Серія : Політичні науки. 2016. № 1. С. 68-71.

\section{Korenkova}

\section{THE EXPERIENCE OF THE BALTIC STATES IN THE FIELD OF EUROPEAN AND EURO-ATLANTIC INTEGRATION}

The relevance of the article is that in order to ensure an effective state policy to implement the national course for European and Euro-Atlantic integration, it is very important to pay attention to the relevant experience offoreign countries that have already achieved this integration and joined the EU and NATO as full members. of particular interest to us is the experience of countries that have become members of these international associations relatively recently, as well as at some historical stage under pressure from the Soviet regime. The European Union is a unique phenomenon of the supranational democratic formation of European countries. The high level of cooperation between European countries in the EU format leads to the fact that every year more and more countries want to join this organization. Therefore, the study of the reform path of these three states is of considerable practical interest for Ukraine. The experience of such Baltic countries as Estonia, Lithuania 
and Latvia deserves priority. The article summarizes the experience of the Baltic states in the field of European and Euro-Atlantic integration, based on the analysis of scientific views of scientists, and emphasizes that the remnants of the Soviet past and Euro-Atlantic integration is not such a significant obstacle. The most positive experience of the Baltic States, which should be used by the Ukrainian legislator, is highlighted. It is concluded that for a high-quality and effective implementation of the course under study in Ukraine, it is necessary to have a coordinated position of political forces in the country on this issue, which has not yet been achieved in our country. Of course, the proclamation of this course in the Constitution of Ukraine was an important step in this direction, but in practice in the political life of the country there are still fierce discussions about the necessity and expediency for Ukraine of such a course. The reluctance of influential political forces to recognize it significantly hinders the adoption and implementation of appropriate measures in this direction. It should be noted that in foreign countries, in particular in the Baltic States and Poland, there was also a significant political struggle for integration, however, after the official recognition of the relevant course, political discussions and disputes concerned the appropriateness or inexpediency of appropriate steps and measures. the choice was not contested or criticized.

Keywords: foreign experience, European integration, Euro-Atlantic integration, improvements, legislation. 